\section{Memento Vienna: A Case Study in Digital Archives, Georeferenced Data and Holocaust Education}

Gl_Forum 2017, Issue 2

Page: 13 - 22

Full Paper

Corresponding Author: wolfgang.schellenbacher@doew.at DOI: 10.1553/giscience2017_02_s13

\author{
Wolfgang Schellenbacher \\ Documentation Centre of the Austrian Resistance, Austria
}

\begin{abstract}
This paper explores a nexus of archival digitization and historical inquiry using the case study of Memento Vienna. Memento Vienna is an online tool, aimed specifically at schools and the general public, that combines datasets and digital collections and georeferences them. The project was led by the Documentation Centre of the Austrian Resistance (DÖW) and is based on the results of decades of digitization work. The project seeks to situate personalized Holocaust histories in Vienna's first district, offering fresh perspectives on archival material, public interaction with archives, and the development of interactive learning, Holocaust education and memorialization. Using GPS, users can interact with the history of their immediate vicinity and access archival material and photographs that document it.
\end{abstract}

\title{
Keywords:
}

Holocaust, digital archives, education, document mapping

\section{Introduction}

Over the past 25 years, the increasing digitization of archival material and the availability of online resources has changed the work of both archives and historians. The sheer volume of entirely digitized archival collections and their online accessibility led Max J. Evans (2010) to argue that 'archivists must shift the way they think about their roles and develop alternative means and methods for doing archival work' (p. 387), notably in order to meet the public expectation (especially of the younger generation) that everything can be found online. Genealogical research, for example, has been driven by increasing public interest, seeing several national and international digitization projects and increased online accessibility of historical sources, such as church and state registers.

Historical science generally and Holocaust studies in particular rely on archival material scattered throughout a large number of archives in different countries. Therefore, this area of science has recently seen attempts to develop innovative new ways of bringing together information from relevant archives and collections, researching and sharing knowledge on the Holocaust. One such project, the EU-funded European Holocaust Research Infrastructure 
(EHRI), created online access to information about dispersed sources relating to the Holocaust, and developed tools and methods that enable researchers and archivists to work collaboratively with such sources (Blanke et al., 2013). Therefore, whilst the last two decades have seen a digital turn in the science of history leading to an increased volume of digital content, it has raised the question of how communicating with and involving members of the general public and school pupils in particular might work, as enhanced availability of data does not necessarily ensure accessibility. To address this, online tools are being developed that facilitate access to digital data and existing material in dynamic and interesting ways.

The inner city of Vienna played an important role in the Nazi period in Austria, and the physical environment has changed very little over the last 80 years. This paper discusses the development and uses of Memento Vienna, an online tool that was developed to map the history of the city centre and its former residents. One particularity of the tool is that it displays information about the immediate vicinity of the user located within Vienna's first district.

For quite some time, it seemed that the application of GIS, while commonly used in various areas of the natural sciences, had not reached the humanities, something pointed out by Bodenhamer, Corrigan \& Harris (2010). Nevertheless, the last 10 years have seen a 'spatial turn' in the social sciences which has also affected historical science. The scholarly debate about Holocaust geographies and the use of GIS has led to new approaches for historians to understand and visualize the Holocaust and its implication for certain areas, cities or former ghettos (see, for instance, Cole (2016) or Knowles, Cole \& Giordano (2014)). However, the use of geo-information in education carried out by many memory institutions is still in its infancy.

Memento Vienna is an attempt to use georeferenced information to create an innovative and easy-to-use tool to comprehensively map data of all Holocaust victims (including political victims of the Nazi regime) in Vienna. The application was created as a mobile website by the Documentation Centre of the Austrian Resistance, in cooperation with the company Braintrust, by georeferencing the last known addresses of Holocaust victims. In this way, buildings and streets as well as whole areas in the city can be transformed into historical sites without any physical intervention in the cityscape. Intuitive navigation makes it possible to access additional information about individuals, including previously fragmented information and documents, as well as photos and explanatory texts. In this way, the fates of the individuals murdered in the Holocaust and the mechanisms of their exclusion, expulsion and eventual murder can be made visible virtually. Memento Vienna is aimed at school groups and teachers, as well as interested members of the general public and tourists.

\section{$2 \quad$ Historical Background}

At the time of the Anschluss of Austria to the German Reich in March 1938, around 185,000 people lived in Vienna who were counted as Jews according to the classifications codified in the Nuremberg Laws. The step-by-step process of the exclusion, disenfranchisement, expropriation and expulsion of Austrian Jews began immediately. With their exclusion from almost all professions came the impoverishment of large parts of the Jewish population. The 
number of Austrian Jews living in Vienna fell rapidly to around 65,500 by September 1939 due to the expulsion policy of the Nazis (Moser, 1999, p. 38). Most of those who stayed behind perished in the Holocaust.

In Vienna, the deportation of Jews started earlier than in other parts of the German Reich, with the first transports leaving Austria in October 1939 and continuing in 1941. However, the systematic mass deportation of the Jewish population from Vienna began in autumn 1941 (Freund, Safrian, \& DÖW, 1993). Between October 1941 and October 1942, around 48,000 Austrian Jews were deported in mass transports to the areas of Central and Eastern Europe occupied by Nazi Germany. Only a small part of the Jewish population remained in Vienna. Many of these approximately 8,000 people lived in so-called 'mixed marriages' with a non-Jewish, 'Aryan' partner. A number of smaller transports that followed further reduced this number.

Of approximately 206,000 Austrians Jews, around 66,500 were murdered during the Holocaust. Additionally, 9,500 Austrian Romani and Sinti and approximately 8,000 Austrian political victims, not to mention the victims of the NS-Euthanasia programme, were murdered in the Holocaust (Bailer, B., Ungar, G., 2013, p. 112). The way that memory institutions use this data and the relevant digital collections influences the commemoration of Holocaust victims. Going beyond broader trends for physical, symbolic or naming memorials, digital initiatives can often personalize victims by including biographical information and photographs.

\section{The Memento Vienna Project}

\section{Aims and Intended Outcomes}

Major social debates (e.g. the Waldheim debate in the 1980s) and generational changes have led to increased public debates on the history of Austria between 1938 and 1945, leading to more open and accessible Holocaust education for pupils. Despite the narratives on the Holocaust and National Socialism communicated in schools and many memory institutions, attitudes in the family conscience towards the events and ideologies of National Socialism are often more determinate than views and images communicated at school (Peham \& Rajal, 2010, p. 47). In recent years, Holocaust education has shifted towards mediating historical content through personalized stories. However, today's schoolchildren are often four and five generations removed from the events (Assmann, 2013, p. 11), and although contemporary witnesses and their testimonies have become a crucial part of Holocaust education, the opportunities to meet and interact with survivors is decreasing. A further factor is the changing demographics in urban areas, specifically where an increasing proportion of children with a migration background necessitates a broader perspective than a familial or regional-based one. Their diverse family backgrounds can make it increasingly difficult to engage with the young people thematically via their individual family history' (Brauckmann, 2015, p. 252). A new immediacy is introduced by presenting life stories that took place locally (within Vienna's first district) for young people using the tool on the 
ground. By mapping archival material and data, the project offers a fresh, additional aspect to modern Holocaust education.

As part of the 'spatial turn' in the historical sciences, the use of GIS has led to new perspectives, opportunities and approaches for historians to map either individual life stories, or to a lesser extent, big data. Memento Vienna is a geo-media tool that documents the fate of individuals using data in the DÖW database. Memento Vienna transforms data on victims and relevant digital holdings into an easily accessible, lively archive of the last place of residence of the victims. Based on maps and the geo-coordinates of specific buildings, it presents information with a strong visual element. The aim of the Memento Vienna project was to create a web application for use primarily - but not exclusively - on mobile devices, enabling the user to interact with Austrian history between 1938 and 1945 on the streets of Vienna, and presenting the lives and fates of those murdered during the Nazi period along with contemporary photographs, archival material and contextual information.

Users can explore the information in the web application in different ways - through name and address searches and, importantly, if they are in Vienna's Innere Bezirk (first district), based on their specific location. An important asset of the Memento Vienna mobile website is therefore the possibility of using the user's current GPS location and of displaying this on the map, offering information about their immediate vicinity (buildings or former addresses of victims/institutions). This aspect of the Memento Vienna website made developing a responsive website a key priority to ensure optimized usability and graphical representation on portable devices such as tablets and smartphones.

Both the technical development of the website and the archival preparation of data relating to Vienna's first district took place in 2016. The mobile website was launched in November 2016 and was accompanied by a special exhibition in January 2017. The project was designed to be expandable, as it is hoped that in the future it might include all of Vienna's 23 districts, and perhaps other Austrian towns and cities. This potential expansion was included in the project planning in order to ensure that any future changes to the scope of the project be easily incorporated.

\section{Target Audience}

Memento Vienna was designed to appeal to school pupils, students and interested members of the general public, as well as to relatives of victims of the Nazi regime. School children, who are 'digital natives', are accustomed to interacting digitally with their immediate vicinity. Developments in technology have made this possible: 'Media in general, and social media in particular, have become increasingly equipped with mapping and location-based features. In other words, media are increasingly becoming like GIS' (Sui \& Goodchild, 2011, p. 1739). Smartphones and tablets additionally bypass the psychological (if not physical) obstacle of visiting archives, facilitating access to the archival material. It is also hoped that by interacting with archival material digitally, people might be encouraged to visit archives. As pointed out by Hulser and Bull (2011), web applications on mobile devices, used for example in museums, 'intrigue the itchy finger public that must do something with their phones' ( $\mathrm{p}$. 207). Many museums have therefore been integrating mobile devices into their pedagogical approaches for a while to help harness this impulse to maximum effect. 
Memento Vienna doesn't aim to replace a profound Holocaust education for schools, and never could. Nor does it hope to replace visits to museums or memorial sites. Rather, mobile applications can supplement educational experiences, helping teachers to prepare for visits to these institutions, encourage exploration of georeferenced information during fieldtrips, and enhance classroom-based teaching and self-directed study. To emphasize the sources of the material such as photos and written documents, each document is accompanied by a link to the holding institution. A short explanation is also offered as to what the document contains, and how and why it was created. Additionally, Memento Vienna tries to communicate the work done by archives and the rich and varied material available.

In terms of content, the focus on targeting a younger audience means that Memento Vienna assumes no extensive previous knowledge of the Holocaust in Vienna. The accompanying texts and descriptions have been kept as short and concise as possible. In keeping with the anticipated target audiences (such as school groups) and also in order to appeal to as many people as possible, succinct and easily understandable texts were important. The complex nature of the research should not result in dense, academic texts. Highly professional users, such as archivists or historians, are not its intended audience.

\section{Archival Research}

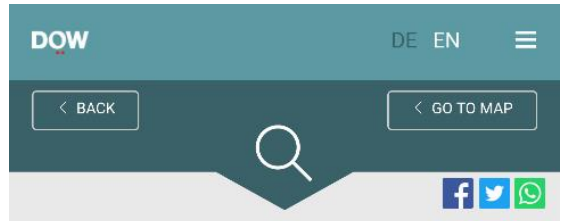

EMIL GOLDMANN

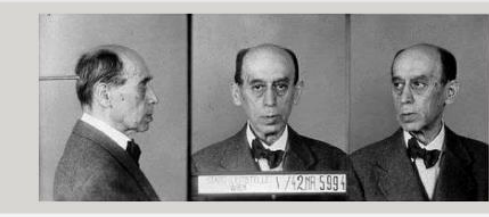

$\begin{array}{ll}\text { First Name } & \text { Emil } \\ \text { Last Name } & \text { Goldmann } \\ \begin{array}{l}\text { Date of birth } \\ \begin{array}{l}\text { Place of } \\ \text { birth }\end{array}\end{array} & \text { Swoikowitz } \\ \begin{array}{l}\text { Date of } \\ \text { death }\end{array} & 01.08 .1942 \\ \end{array}$

Figure 1: Detailed information on the fate of a Holocaust victim, with a photo taken by the Gestapo Vienna
Memento Vienna is based on previously digitized archival collections, which are connected to the database of victims and assigned geo-information (see section 3.4 for more detail). Therefore, Memento Vienna concentrates less on ego documents of the victims and more on broader collections of documents. Further archival research was carried out in several relevant archives in Austria and abroad, and various datasets were cross-referenced to painstakingly piece together information about individuals. For example, documents relating to 541 people from the KZVerband (an association of former concentration camp prisoners or their relatives) who had their addresses in the first district after 1945 were cross-referenced with people known to have been living in the first district before the war and also known to have been murdered (in keeping with the Austrian rules for data protection to exclude any person who might still be alive). This rendered 45 names. A total of 5,125 names were included in the version that launched in November 2016, but the hope remains that, as new data becomes available, Memento Vienna will be updated to include it.

Deportation lists from the large-scale transports were key archival sources, as were identity photographs 
taken by the Gestapo Vienna (see Figure 1), information from the Daily Reports published by the Gestapo, and material from archives in Czechia and Israel, all of which helped to add more information to the biographies of the people included. Roughly 15,000 Austrians were deported to the Theresienstadt Ghetto from 1942, making it the place to which the highest number of Austrian Jews were deported. Working in collaboration with the Institut Theresienstädter Initiative (ITI), it was possible to include scans of so-called Todesfallanzeigen (death records) that had already been digitized by the ITI and made available online. These records were linked to the DÖW database and made available to view as part of Memento Vienna.

Following an extensive literature review and additional archival research on the topography of the Nazi regime in Vienna, further addresses were added, including those of organizations related to Jewish life in the city, as well as instruments of persecution, theft and deportation. These places are also made visible on the map. Every key location for the expulsion and deportation of the Jews was included, supplemented by photographs, documents and short summary texts.

Written documents have also been supplemented by photographs from the DÖW's collections. A symbolic selection of photographs of victims of the Nazi regime were also used on the welcome page of the mobile website. Photographs of buildings from the period were found in the Vienna Municipal and Provincial Archives, and the Bildarchiv Austria of the Austrian National Library (see Figure 2). Access to these archives allowed us to find photographs for roughly $45 \%$ of the personal and institutional addresses identified.

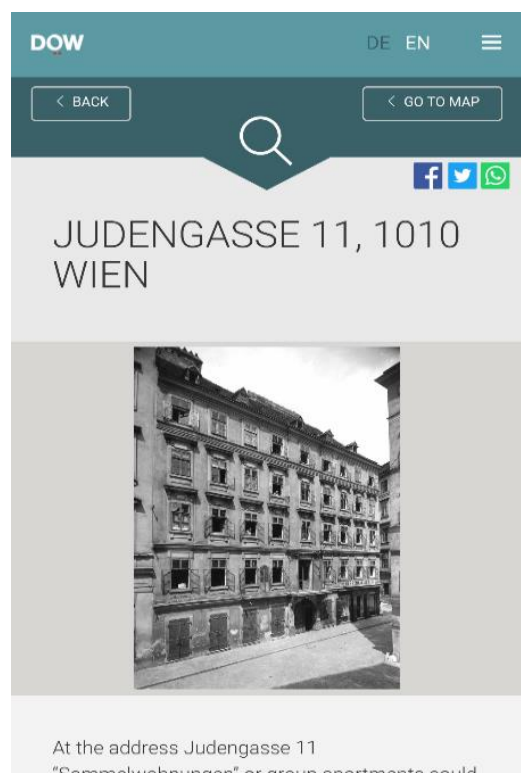

Figure 2: Location-specific detail with a contemporary photograph of the building

\section{Merging and mapping archival sources}

As noted in recent literature on the use of GIS in the historical sciences: 'Our sense is that developing a wide-ranging historical GIS of the Holocaust would provide a crucial context for reading and better contextualizing one of the key sets of sources in Holocaust studies: diaries, memoirs, and oral testimony. It would literally place these individual stories' (Knowles, Cole, Giordano, 2014, p. 151). Any attempt to map the Holocaust in a city like Vienna is dependent on access to large and reliable datasets on Holocaust victims to which georeferenced information, historical information and scans of documents can be added.

The personal data used for Memento Vienna was based predominantly on the database(s) of victims that the DÖW had created over the last 25 years. Through the project Registration by Name: Austrian Victims of the Holocaust and subsequent work, the names of 64,000 of the 66,500 Austrian victims of the Shoah were be identified. The project was initiated in 1987 by Yitzhak Arad, then head of Yad Vashem (the international Holocaust Remembrance Center, Jerusalem), and commissioned by the Austrian Ministry for Sciences in 1992 (Bailer \& 
Ungar, 2008, p. 93). After evaluating the transport lists of the mass transportations of Jews to the areas occupied by the Nazis in East-Central Europe, information from other sources such as the holdings of the Opferfiursorge Wien and other memorial sites was later added. This way several databases on victims of the Holocaust were compiled, including data on 64,000 of the 66,500 Austrian Jewish victims of the Holocaust. Since the early 2000s, these results have been searchable online, along with 4,600 identity photographs taken by the Gestapo Vienna.

In 2015, digital copies of transport lists were linked to the individual victims, making 47,000 records about the individual victims available on the DÖW's homepage. This made it possible to produce a list of the Shoah victims from Vienna's first district, including over 5,000 people whose last address before deportation was in the district. As mentioned above, to encourage users to interact directly with the data and the stories represented in the immediate area, particular emphasis was placed on the last addresses of Shoah victims before deportation. The list - made up of first and second names, date of birth, last known address, deportation date, place to which deported, and date of death - formed the basis for the later editing of the data.

The existing archival data was linked to georeferenced information, assigning a geocoordinate to each address. This work was done manually as addresses which no longer exist are included - for example, ones destroyed by bombing during the war (e.g. the former Kohlmessergasse, today part of Schwedenplatz); such addresses can only be located on a map nowadays by using georeferences. A further step entailed extracting the addresses of the victims, which generated 650 addresses in the first district.

\section{User Experience}

To ensure sustainability, Memento Vienna used basemap.at, the result of a cooperation between all the Austrian provinces, based on administrative data (Schmidt \& Jörg, 2012). basemap.at was created as the first digital web base map for the whole of Austria and went online in 2014. It is an OGC-conform Web Map Tile Service at a scale of 1:1000, allowing users to see the exact shapes of buildings or streets, and is available for private as well as for commercial purposes according to the open government data conditions in Austria (Jörg, 2015).

Designed to be as intuitive as possible, the map of Vienna is centred at the user's location (shown on the map using a red location symbol), but can be manipulated by zooming in or out, or scrolling around different areas of the city. Included in the maps are standardized icons, representing different types of information available for specific addresses. By tapping on an icon, an overlay appears with a summary of information available (see Figure 3) for the particular location (address, and number of victims who lived in the building). 
The navigation principles are based on current usability concepts as they apply to mobile applications (for example, drop-down menus as the main navigation tool, context-specific detail options, and a 'back' button). In order to facilitate use by tourists and the descendants of victims, all aspects of Memento Vienna are available in both German and English. It is possible to switch between the versions at any time.

Tapping the overlay leads to a page with much more detailed information, such as a list of the names of people who had this address as their last known place of residence before deportation, and archival material such as photographs and documents. There are two options (in keeping with the two possible icons shown in the map display): person-related information, or information about the address (e.g. organizations or institutions based there).

The person-specific information pages offer data from the victims' database of the DÖW. In most cases, this is the first and last name, date and place of birth, date and place of death, the number of the

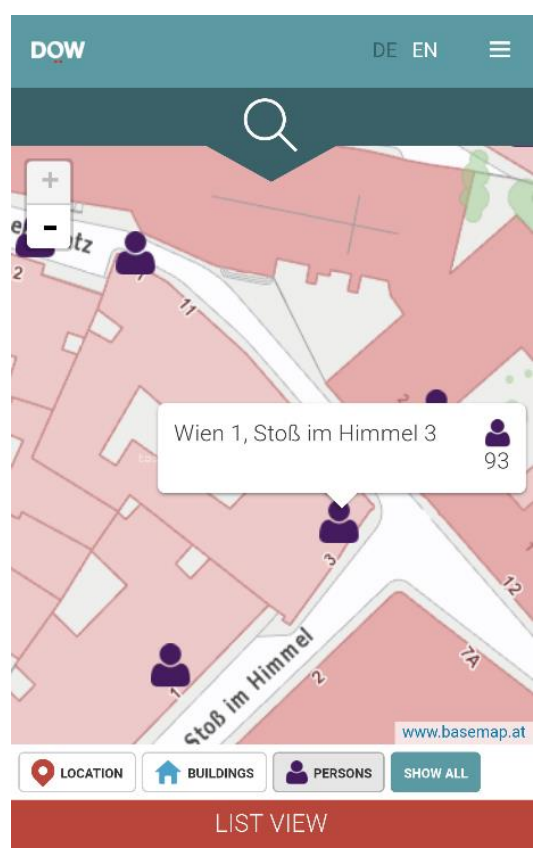

Figure3: Map zoomed in to show address with overlay transport they were deported on and deportation date. Furthermore, individuals are all linked to pictures, documents and texts, where available. The archival material available in the DÖW was supplemented by further documentation scattered throughout archives both in Austria and abroad to offer a fuller picture of the exclusion, deportation and persecution processes during the Nazi period.

The location-specific information pages feature addresses and names - where available of organizations and institutions, both those set up to help and assist the victims of persecution, and those established to persecute through systematic theft, exclusion and deportation. Where possible, photographs of the buildings from the 1930s and 1940s have been included with related documents.

As an alternative to the map display, addresses, buildings and people can also be viewed as a list. The user can switch between the list and map views at any time. It is also possible to search for addresses. After entering a search term, the map will re-centre on the chosen address. Selecting the object will again lead the user to the detailed information pages, as described above.

Partly to appeal to younger users but also to allow content from the web application to reach as broad an audience as possible, social media integration was important. Information such as photographs, texts and data from a page can be shared directly via Twitter, Facebook and WhatsApp. 


\section{$4 \quad$ New Research questions}

Memento Vienna was created as a user-friendly, online tool visualizing digital content relating to the fate of Holocaust victims. However, in compiling and presenting the data, it became clear that this new approach to present archival information also provides new opportunities for historians: 'digital content can enable new insights into historical questions [...], helping researchers to ask new research questions that are driven by insights that were only achievable through this use of digital content, tools and methods' (Hughes, 2016, p. 226).

The spatial analysis of the database of victims by using GIS has led to new insights into the Holocaust in Vienna: Memento Vienna made the identification of 140 of the so-called Judenhäuser (Jew houses) in the first district possible and visible. These were buildings and apartments owned or already tenanted by Jews to which the Viennese Wohnungsamt (Apartment Office) started to relocate Jews in 1939. In this way, buildings in the so-called 'textile quarter', and around Rotenturmstraße especially, would become the last addresses for many victims before their deportation and murder.

New insights could also be gained into the demographic development and distribution of the Jewish population. The average age and gender of the victims in certain areas would be a viable new area for research.

\section{Conclusion}

Memento Vienna represents a nexus of archival digitization and historical inquiry using a combination of datasets to produce a tool for non-specialist audiences. Designed as a project that could be expanded further (depending on funding), it represents a starting point for using digital collections linked to georeferenced information, offering fresh perspectives on archival material, public interaction with archives, and the development of interactive learning and Holocaust education and memorialization. Seen in the wider context of Holocaust-related projects specifically designed to link disparate collections, Memento Vienna, which has a strong spatial component, is a starting point for the dynamic examination and discovery of previously unexplored aspects of Holocaust history.

\section{Acknowledgements}

Memento Vienna was supported by the Austrian Federal Ministry of Science under Grant number 3.023/0005-WF/V/10b/2015, Research and Economy; the National Fund of the Republic of Austria for Victims of National Socialism; and the Future Fund of the Republic of Austria under Grant number P15-2157. 


\section{References}

Assmann, A. (2013). Das neue Unbehagen an der Erinnerungskultur. Eine Intervention. Munich: C. H. Beck Verlag

Bailer, B., Ungar, G. (2008). Die namentliche Erfassung von Opfern des Nationalsozialismus. In DÖW (Ed.), Bewahren Erforschen Vermitteln - Das Dokumentationsarchiv des österreichischen Widerstandes, pp. 91-108

Bailer, B., Ungar,G. (2013). Die Zahl der Todesopfer politischer Verfolgung - Ergebnisse des Projekts. In DÖW (Ed.), Opferschicksale: Widerstand und Verfolgung im Nationalsozialismus, pp. 111-124

Blanke, T., Vanden Daelen V., Frankl M., Kristel C., Rodriguez K., Speck R. (2013).

The Past and the Future of Holocaust Research: From Disparate Sources to an Integrated European Holocaust Research Infrastructure. In Neuroth, H., Lossau, N., Rapp A. (Eds.), Evolution der Informationsinfrastruktur - Kooperation zwischen Bibliothek und Wissenschaft, pp. 157-177. DOI: $10.3249 /$ webdoc-39006

Bodenhamer, D., Corrigan, J., Harris, T.M. (2010). The Spatial Humanities - GIS and the Future of Humanities Scholarship. Bloomington, IN: Indiana University Press

Brauckmann, S. (2015). 'How do you wish to remember?' - Youth Participation and Culture Remembrance Using Geo-Information. In A. Car, T. Jekel, J. Strobl \& G. Grie $\neg$ seb $\neg$ ner (Eds.), GI_Forum 2015 - Geospatial Minds for Society, 251-260. DOI: 10.1553/giscience2015

Cole T. (2016). Holocaust Landscapes. London; New York: Bloomsbury

Evans, M.J. (2007). Archives of the People, by the People, for the People. The American Archivist, $70,387-400$

Freund, F., Safrian H. (Eds.) (1993). Vertreibung und Ermordung. Zum Schicksal der österreichischen Juden 1938-1945. Das Projekt 'Namentliche Erfassung der österreichischen Holocaustopfer'. Vienna: DÖW

Hughes, L. M. (2016). Finding Belgian refugees in Cymru1914.org: using digital resources for uncovering the hidden histories of the First World War in Wales. Immigrants \& Minorities Historical Studies in Ethnicity, Migration and Diaspora, (34)2, 210-231

Hulser, K., Bull, S., (2011). Click History: Wherever, Whenever. In I. Katz, W. LaBar, \& E. Lynch (Eds.), Creativity and Technology - Social Media, Mobiles and Museums. Boston, MA: MuseumsEtc

Jörg, W. (2015). basemap.at - DIE administrative Grundkarte von Österreich. In 18. Internationale Geodätische Woche Obergurgl 2015, 37-43

Knowles, K., Cole, T., \& Giordano, A. (2014). Geographies of the Holocaust. Bloomington, IN: Indiana University Press

Moser, J. (1999). Demographie der jüdischen Bevölkerung Österreichs - 1938-1945, Vienna: Schriftenreihe des DÖW zur Geschichte der NS-Gewaltverbrechen, 5

Peham, A., Rajal E. (2010). Erziehung wozu? Holocaust und Rechtsextremismus in der Schule. In DÖW (Ed.), Jahrbuch 2010, pp. 38-65

Schmidt, M., Jörg, W. (2012). basemap.at - Creating a Harmonised Web Basemap for Austria. In Service-Oriented Mapping 2012, Jobst Media Verlag, Vienna, pp. 143-149

Sui, D., Goodchild M. (2011). The convergence of GIS and social media: challenges for GIScience. International Journal of Geographical Information Science, 25(11), 1737-1748 